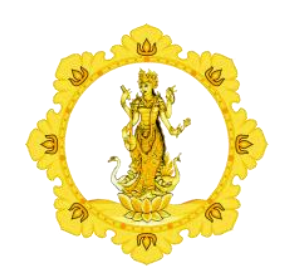

KALANGWAN

JURNAL PENDIDIKAN AGAMA, BAHASA DAN SASTRA

Vol. 9 No. 2 September 2019

\begin{tabular}{|l|l|l|}
\hline p-ISSN : 1979-634X & e-ISSN : 2686-0252 & http://ejournal.ihdn.ac.id/index.php/Kalangwan \\
\hline
\end{tabular}

\title{
ANALISIS STRUKTUR YANG TERKANDUNG DALAM CERPEN UMAH
}

\author{
Oleh : \\ Ni Luh Putu Nitahapsari Rahayu \\ Institut Hindu Dharma Negeri Denpasar \\ E-mail: nitaputu12@gmail.com
}

Diterima 22 Juli 2019, direvisi 20 Agustus 2019, diterbitkan 2 September 2019

\begin{abstract}
Literary works are creations communicated expressively about the author's intent for aesthetic purposes. This study examines the intrinsic contained in the short story of Bali language entitled "umah" generally have opinions and different interpretation of a short story. The intrinsic element is all the outside elements that underlies and creation of literary works. The method used in this research descriptive research using descriptive research method. Method is a methodthe status of a human group, an object, a set of conditions, a system ofthought, or a classof events in the present. In the analysis of the short stories in Bali language, the work of this I Dewa Ketut Raka Kusuma, contains many moral values and social value that can be taken and learned by the readers.
\end{abstract}

Keywords: karya sastra, cerpen

\section{PENDAHULUAN}

Sastra (Sanskerta: shastra) merupakan kata serapan dari bahasa Sanskerta 'Sastra', yang berarti "teks yang mengandung instruksi" atau "pedoman", dari kata dasar "Sas' yang berarti "instruksi" atau "ajaran" dan 'Tra' yang berarti "alat" atau "sarana". Dalam bahasa Indonesia kata ini biasa digunakan untuk merujuk kepada "kesusastraan" atau sebuah jenis tulisan yang memiliki arti atau keindahan tertentu.

Yang agak bias adalah pemakaian istilah sastra dan sastrawi. Segmentasi sastra lebih mengacu sesuai defenisinya sebagai sekedar teks. Sedang sastrawi lebih mengarah pada sastra yang kental nuansa puitis atau 
abstraknya. Istilah sastrawan adalah salah satu contohnya, diartikan sebagai orang yang menggeluti sastrawi, bukan sastra.

Selain itu dalam arti kesusastraan, sastra bisa dibagi menjadi sastra tertulis atau sastra lisan (sastra oral). Di sini sastra tidak banyak berhubungan dengan tulisan, tetapi dengan bahasa yang dijadikan wahana untuk mengekspresikan pengalaman atau pemikiran tertentu.

Astra bukanlah seni bahasa belaka, melainkan suatu kecakapan dalam menggunakan bahasa yang berbentuk dan bernilai sastra. Jelasnya faktor yang menentukan adalah kenyataan bahwa sastra menggunakan bahasa sebagai medianya. Berkaitan dengan maksud tersebut, sastra selalu bersinggungan dengan pengalaman manusia yang lebih luas daripada yang bersifat estetik saja. Sastra selalu melibatkan pikiran pada kehidupan sosial, moral, psikologi, dan agama. Berbagai segi kehidupan dapat diungkapkan dalam karya sastra

Sastra dapat memberikan kesenangan atau kenikmatan kepada pembacanya. Seringkali dengan membaca sastra). Dalam muncul ketegangan-ketegangan (suspense ketegangan itulah diperoleh kenikmatan estetis yang aktif. Adakalanya dengan membaca sastra kita terlibat secara total dengan apa yang dikisahkan. Dalam keterlibatan itulah kemungkinan besar muncul kenikmatan estetis. Cerpen adalah karangan pendek yang berbentuk prosa. Dalam cerpen dipisahkan sepenggal kehidupan tokoh, yang penuh pertikaian, peristiwa yang mengharukan atau menyenangkan, dan mengandung kesan yang tidak mudah dilupakan (Kosasih dkk, 2004:431).

Nugroho Notosusanto (dalam Tarigan, 1993:176) mengatakan bahwa cerpen adalah cerita yang panjangnya di sekitar 5000 kata atau kira-kira 17 halaman kuarto spasi yang terpusat dan lengkap pada dirinya sendiri.

Menurut menurut, H.B. Jassin Sang Paus Sastra Indonesiamengatakan bahwa: yang disebut cerita pendek harus memiliki bagian perkenalan, pertikaian, $\&$ penyelesaian..

\section{PEMBAHASAN}

Sinopsis cerita adalah merupakan ringkasan cerita dari sebuah novel atau gambaran isi dari suatu cerita secara garis besarnya. Sinopsis biasanya digunakan sebagai prolog dalam sebuah naskah, baik naskah pendek maupun panjang untuk sebuah pementasan drama, film dan terater panggung. Sinopsis ini dibuat untuk memudahkan dalam mengetahui dan memahami secara singkat tentang sebuah naskah yang akan dipentaskan atau dibaca. Dalam penulisannya biasanya sinopsis ini dibatasi dengan jumlah halaman, misalnya 1 sampai 3 halaman saja atau seperlima dari panjang karangan aslinya. Dan dalam penulisan sinopsis tidak membutuhkan gaya bahasa dan penjelasan-penjelasan yang luas, akan tetapi isi atau gagasan umum lebih diutamakan.

\section{Sinopsis cerpen "umah"}

Pak Guru Sukadana masuk kedalam kelas, seperti biasa murid-murid mengucapkan salam "om swastiastu", setelah pak guru menaruh tas, pak guru memberikan tugas menggambar rumah kepada para murid. Karena hari ini para guru akan rapat evaluasi maka pak guru Sukadana tidak bisa menemani para siswa untuk menggambar. 15 menit berlalu, Gede Wiradana belum menggambar apapun. Karena ia tidak memiliki rumah yang layak yang bisa dia gambar, ia terus membayangkan rumah mewah beserta harta bendanya. Tetapi itu hanya angan-angan saja, ia tidak akan bisa memiliki rumah seperti itu karena lima tahun yang lalu orang tuanya bercerai, ayahnya yang suka metajen dan memitra yang membuat ibunya tidak tahan dengan sikap ayahnya lalu ibunya memilih untuk pergi bersama Gede Wiradana ke puri kesiman kediaman teman ibunya pada saat kuliah, disana Gede Wiradana dan ibunya bekerja sebagai pembantu di purinya Sagung Dwipayani teman ibunya semasa kuliah. Saat Gede Wiradana ditanyakan oleh ajik Sagung Dwipayani tentang kelanjutan sekolahnya Gede Wiradana, ajik Sagung Dwipayani memilih untuk menyekolahkan Gede 
Wiradana di SD terdekat disana jatuhnya tempat duduk dari belakang membangunkan lamunan Gede Wiradana dari lamunanya, ternyata ia belum membuat gambaran satu pun. Lalu pak guru Sukadana dating, dan para siswa segera mengumpulkan tugasnya, tetapi tidak dengan Gede Wiradana.

\section{a. Tema}

a. Tema adalah rumusan masalah atau pokok pikiran yang menjadi dasar cerita. Ide cerita yang mengubah karangan yang berdasarkan dari pandangan kehidupan, pengetahuan, pengalaman,emosi,dan imajinasi pengarang (Sudjiman,2003:50). Willem, mengetahui teman adalah pandangan kehidupan atau rangkaian nilai-nilai yang membentuk atau membangun disarm dan gagasan yang utama dalam karya sastra (1984:51). Tema merupakan apa yang menjadi pikiran atau yang menjadi masalah oleh pengarang. Tema menjadi masalah yang mengetahui dalam cipta sastra. Demikian masih bersifat netral, belum mempunyai kecenderungan yang memihak, karena itu masih menjadi masalah.

Tema yang terdapat dalam cerpen berbahasa Bali yang berjudul "umah" adalah konflik sosial dalam keluarga dimana, orang tua dari gede wiradana sudah bercerai karena ayahnya yang suka memotoh dan memitra.

Kutipan : Mirib sing sida naanang sakit ati, atiban ané liwat, méménné nuturin bapanné apang suud ja ngantén-palas, mamitra miwah mamotoh. Dugasé ento Gedé Wiradana sedek di pasaréanné. Gelem matbat méménné aji munyi sing dadi dingehang baan koping. Suud matbat, memenné tundunga apang magedi jani ja. Méménné macelep ka kamar tongosné Gedé Wiradana masar matamped-tamped.
Alih bahasa : mungkin tidak ada yang bisa menandingi rasa sakit hati ibunya dan ingin segera bercerai karena ayahnya yang suka selingkuh dan bermain sambung ayam. Gede Wiradana pada saat itu sedang tidur karena sakit.

\section{b. Tokoh dan Penokohan}

Tokoh dan penokohan merupakan individu ciptaan atau rekaan yang mengalami peristiwa-peristiwa atau lakon dalam setiap pristiwa cerita. Tokoh berwujud manusia, tetapi ada juga yang berwujud binatag atau benda yang digunakan tokoh.

Ada dua jenis tokoh bila dilihat dari sisi keterlibatannya dalam menggerakan alur, yaitu:

1.Tokoh sentral merupakan tokoh yang amat potensial menggerakan alur. Potensial $\rightarrow$ mempunyai potensi, dimana arti potensi adalah sesuatu yang dipandang dapat menghasilkan/ menguntungkan. Tokoh sentral merupakan pusat cerita, penyebab munculnya konflik. 2.Tokoh bawahan merupakan tokoh yang tidak begitu besar pengaruhnya terhadap prkembangan alur, walaupun ia terlibat juga dalam pengembangan alur itu

a. Tokoh sentra adalah tokoh utama merupakan lakon yang diceritakan dalam cerita dan mendominasi cerita (Taringan,1984:141). Tokoh utama dalam cerpen berbahasa Bali berjudul "umah", semua itu dapatdilihat dalamkutipan cerita sebagai berikut:

Kutipan : Gedé Wiradana nu natakin jagut nlektekang buku gambar ané makebat duur mejanné. Limanné ngamel potlot. Tekek. Nanging sing sida ngorékang.

Alih bahasa : Gede Wiradana masih bengong melihat buku gambarnya yang terbuka di atas mejanya. Tanganya yang memegang pensil, erat tapi tidak bisa ia tuliskan 
Kalimat di atas menyebutkan tokoh utama yang ada dalam cerpen berbahasa bali yang berjudul "umah". Tokoh utama yang disebut diatas adalah Gede Wiradana. Tokoh utama tersebut menjadi pokok pembahasan, paling sering muncul dalam perkembangan cerita dalam cerpen "umah" . kutipan tersebut merupakan bukti adanya tokoh utama yang ada dalam cerpen "umah". Selanjutnya terdapat penokohan dalam tokoh utama yaitu Sagung Dwipayanti, dapat dilihat dari kutipan

Kutipan : . Timpal méménné uli SD kanti SMA. Sakéwala disubanné tamat SMA Sagung Dwipayani mawali ka Puri Kesiman. Déning ajin idané ané dadi polisi suba pénsiun. Sagung Dwipayani kuliah ring Universitas Udayana. Memenné kuliah di IKIP Singaraja, nanging sing lantur. Ané ngranaang, ngantén dugasé mara ngenjek seméster telu. Sayan kangén kenehné nepukin Sagung Dwipayani nangis dugas méménné ngaturang unduké ané nepén tur ngaturang sing lakar mabalik buin ka Klungkung.

Alih bahasa: teman ibunya dari SD sampai kuliah, tetapi setalah tamat kuliah Sagung Dwipayani kembali ke puri kesiman, karena ayahnya yang menjadi polisi sudah pension. Sagung Dwipayani dahulu kuliah di Universitas Udayana dan ibunya kuliah di IKIP Singaraja, tapi tidak berlanjut karena menikah pada semester tiga. Saking terharunya Sagung Dwipayani melihat ibunya Gede Wiradana sampai ia menangis karena ibunya Gede Wiradana menceritakan nasibnya yang membuat ia kembali ke klungkung

Kutipan diatas menyatakan karakteristik Sagung Dwipayani. Dilihat dari cerepn "umah" ini Sagung Dwipayanti memiliki karakter yang penyayang, dan setia dengan teman

\section{c. Tokoh bawahan}

Menurut Abrams (dalam nurgiyantoro ,2010:165), tokoh bawahan adalah tokoh yang tidak sentral kedudukanya dalam cerita tetapi tokoh tersebut sangat berguna untuk mendukung peran tokoh utama. Semua itu dapat dilihat dari penggalan cerita berikut ini :

Kutipan : Mara limané lakar ngorékang potlot sig buku gambaré, sagét Pak Guru Gusti Sukadana ngranjing ka kelasé.

"Alit-alité, sampun usan ngambar?" Pak Guru Gusti Sukadana matakén di subané malinggih. "Ampun!" murid-muridé, sajaba Gedé Wiradana, sibarengan masaut. "Yén sampun bakta mriki!"

Alih bahasa: baru tanganya akan menggambar di buku gambarnya, tiba-tiba Pak guru dating ke kelas. "anak-anak, sudah selesai menggambar?”. Pak guru bertanya sesudah ia duduk. "sudahhh!". Murid-murid seperti Gede Wiradana menjawab. "jika sudah bawa kemari!"

Kutipan diatas mencirikan tokoh bawahan yang ada dalam cerpen "umah". Tokoh bawahan yang disebut diatas adalah Pak Guru Gusti Sukadana guru dari Gede Wiradana disebutkan memiliki karakter yang bijaksana . penokohan tersebut disebutkan dalam kutipan berikut :

Kutipan : Alit-alité sareng sami," Pak Guru Gusti Sukadana mabaos, di subané ngenahang tas duur méjané, "medalang buku gambaré. Gambar umah, jero, puri, utawi grian duéné suang-suang. Sampunang uyut. Bapak ten nongosin alit-alité.". "Jagi kija, Pak?" Nyoman Antara nyelag aji patakon."

Alih bahasa : "anak-anak semua". Pak guru berkata sambil meletakan tas diatas meja, "keluarkan buku gambar, gambarlah rumah kalian masing-masing, jangan rebut. Bapak tidak akan mengawasi kalian karena bapak ada rapat.

Yang kedua ada tokoh bawahan lain yaitu, biangné Sagung Dwipayani yang merupakan Ibu dari Sagung 
Dwipayani. Berikut kutipan dari Biangné Sagung Dwipayani

Kutipan : Biangné Sagung Dwipayani tengkejut nyingakin sapatekan méménné. Ida raris nandan méménné tur ngaukin déwékné ka purian. Sayan tengkejut biangné Sagung Dwipayani mirengang unduk ané nepén méménné. Gerungan mobil di garasané megat atur méménné. "To Sagung Dwipa rauh," biangné Sagung Dwipayani ngandika

Alih bahasa: ibunya Sagung Dwipayani terkejut melihat ibunya GedeWiradana, beliau lalu menuntun ibunya Gede untuk masuk ke puri. Lagi ibunya Sagung Dwipayani terkjut saat ibunya Gede menuturkan masalahnya, lalu bunyi mobil dari garasi memotong pembicaraanya. "itu Sagung sudah datang”. Kata ibunya

Penokohan dari biangné Sagung Dwipayani yaitu bliau sangat bijaksana dan patuh terhadap suami, dimana karakter tersebut terdapat dalam kutipan :

Kutipan : "Kanggo biang tiangé," Sagung Dwipayani masaur, "sapunapi biang, icén ipun ngayah driki?". "Antiang malu $i$ aji," alon masaur biangné Sagung Dwipayani.

Alih bahasa : "terserah ibu". Kata Sagung Dwipayani. " bagaimana ibu, apakah dia akan bekerja disini?". "tunggu ayahmu dulu”. Kata ibu Sagung

\section{d. Latar (tempat cerita)}

Latar adalah segala keterangan, petunjuk, acuan yang berhubungan dengan waktu, tempat, situasi yang ada dalam cerita (Panuti, 1991:44). Latar atau seting adalah lingkungan atau tempat peristiwa yang dilaksanakan dalam konteks cerita (Antara,2008:08). Seperti yang sudah dipaparkan diatas, dapat disimpulkan latar tersebut adalah tempat, waktu, suasana dan yang lainya yang berhubungan dengan tokoh utama dan tokoh bawahan pada isi cerita. Latar yang terdapat dalam cerpen berbahasa Bali "umah" seperti pada berikut ini
1. Latar tempat adalah keterangan mengenai ruang terjadinya peristiwaperistiwa di dalam suatu karya sastra. Latar tempat yang ada di dalam cerpen berbahasa Bali "umah" adalah di ruang kelas, Batubulan, Puri Kesiman Kutipan di ruang kelas : Alit-alité sareng sami," Pak Guru Gusti Sukadana mabaos, di subané ngenahang tas duur méjané, "medalang buku gambaré. Gambar umah, jero, puri, utawi grian duéné suang-suang. Sampunang uyut. Bapak ten nongosin alitalité."

Alih bahasa: "anak-anak semua". Pak guru berkata sambil meletakan tas diatas meja, "keluarkan buku gambar, gambarlah rumah kalian masing-masing, jangan rebut. Bapak tidak akan mengawasi kalian karena bapak ada rapat

Kutipan di Batubulan : Naanang gelem ia negak di samping méménné di tengah bisé ané lakar luas ka Batubulan. Gedé Wiradana sing bani matakon, ngudiang sing menék sig bisé ané luas ka Buléléng. Tongos palekadan méménné.Teked di Batubulan, tuun uli bisé, ia nututin méménné majalan ngojog mobil angkot ané luas ka Kreneng.

Alih bahasa : dengan menahan rasa sakit, ia duduk di samping ibunya di dalam bus yang akan pergi ke Batubulan. Gede tidak berani bertanya, mengapa tidak menaiki bus yang pergi ke Buleleng tempat lahir ibunya, sampai di Batubulan turun dari bus, ia mengikuti ibunya berjalan menuju angkot yang akan ke Kreneng

Kutipan di puri kesiman : Biangné Sagung Dwipayani tengkejut nyingakin sapatekan méménné. Ida raris nandan méménné tur ngaukin déwékné ka purian. Sayan tengkejut biangné Sagung Dwipayani mirengang unduk ané nepén méménné.Gerungan mobil di garasané megat atur méménné. "To Sagung Dwipa rauh," biangné Sagung Dwipayani ngandika. 
Alih bahasa: ibunya Sagung Dwipayani terkejut melihat ibunya GedeWiradana, beliau lalu menuntun ibunya Gede untuk masuk ke puri. Lagi ibunya Sagung Dwipayani terkjut saat ibunya Gede menuturkan masalahnya, lalu bunyi mobil dari garasi memotong pembicaraanya. "itu Sagung sudah datang". Kata ibunya

Dari kutipan tersebut didapat latar tempat dimana peristiwa dalam cerpen berbahasa bali berjudul "umah"

2. Latar waktu adalah keterangan tentang kapan peristiwa itu terjadi. Pada cerpen "umah" terdapat kutipan yang menunjukan latar waktu, seperti

Kutipan : . Dugasé ento Gedé Wiradana sedek di pasaréanné. Gelem. Bapanné brangti tuturina baan méménné. Mabukti, dingeha bapanné matbat méménné aji munyi sing dadi dingehang baan koping. Suud matbat, memenné tundunga apang magedi jani ja. Méménné macelep ka kamar tongosné Gedé Wiradana masar matamped-tamped.

Alih bahasa: Gede Wiradana pada saat itu sedang tidur karena sakit. Ayahnya yang keras kepala diberikan nasihat oleh ibunya. Tetapi malah sebaliknya ibunya Gede yang di salahkan atas kemiskinan ini, lalu ayahnya Gede mengusir ibunya, lalu ibunya masuk ke kamar untuk mengemasi baju

3. Latar suasana adalah situasi yang terjadi ketika si tokoh melakukan sesuatu. Pada cerpen "umah" terdapat kutipan yang menunjukan latar suasana, seperti:

Kutipan : Kangén kenehné Gedé Wiradana nepukin méménné magelut ajak Sagung Dwipayani. Sayan kangén kenehné nepukin Sagung Dwipayani nangis dugas méménné ngaturang unduké ané nepén tur ngaturang sing lakar mabalik buin ka Klungkung.
Alih bahasa : terasa terharu Gede melihat ibunya berpelukan dengan Sagung Dwipayani . Dari kutipan tersebut, dapat diketahui bahwa latar suasana pada cerpen "umah" tesebut adalah suasana terharu.

\section{e. Alur}

Alur atau plot cerita adalah kerangka dasar dalam cerita. Selanjutnya plot boleh disebut sebagai susunan peristiwa-peristiwa atau isi dalam cerita seperti interaksi fungsional dan segala yang menyatakan bagianbagian dalam cerita (sutresna,2006:55). Bentuk alur karya sastra dibagi menjadi dua yaitu, alur lurus dan alur sorot balik atau flashback. Dikatakan alur lurus jika peristiwa dalam cerita tersebut memulai dari permulaan,tengah, dan akhir. Selain daripada itu disebut alur sorot balik atau flashback seperti urutan cerita yang tidak berurutan.

Sesuai dengan penjelasan diatas, dapat disebutkan dalam cerpen "umah" menggunakan alur flashback, yaitu urutan ceritanya yang tidak berurutan.

a. Permulaan

Permulaan dalam cerpen "umah"dilihat dari pendahuluannya. Permulaan dalam karya sastra cerpen berisikan tentang perkenalan guru terhadap para muridnya. Pada permulaan ini dibuat agar dalam menyurat karya sastra tersebut tidak menemui rintangan, seperti contoh berikut ini :

Kutipan : Pak Guru Gusti Sukadana ngranjing ka tengah kelasé. Murid-muridé ngaturang panganjali. "Alit-alité sareng sami," Pak Guru Gusti Sukadana mabaos, di subané ngenahang tas duur méjané, "medalang buku gambaré. Gambar umah, jero, puri, utawi grian duéné suang-suang. Sampunang uyut. Bapak ten nongosin alitalité." 
Alih bahasa : : "anak-anak semua". Pak guru berkata sambil meletakan tas diatas meja, "keluarkan buku gambar, gambarlah rumah kalian masing-masing, jangan rebut. Bapak tidak akan mengawasi kalian karena bapak ada rapat

Penggaan kutipan diatas menjelaskan ketika seorang guru dengan bijaksana memberikan tugas menggambar kepada para siswa, dan bapak guru tersebut tidak bias mendampingi para siswa untuk membuat gambaran yang ditugasi. Tujuanya agar para siswa mau belajar mandiri

\section{b. Pertengahan}

Selanjutnya pada pertengahan, dalam cerpen ini pertengahanya bisa dilihat dari inti cerpen "umah". Karena itu yang menjadi inti sari dari cerpen ini bisa dilihat dari penggalan berikut:

Kutipan : déwékné akorékan tondén ngambar.Gedé Wiradana ngunjal angkihan. Sing aséna, munyi maclepeh uli kenehné. Kénkénang abeté ngambar. Yén gambar cara umahé di Klungkung suba sing gelah. Yén gambar cara puri tongosé ngayah, masi tusing gelah. Laut ia nyledétin Wayan Darmawan ané negak di sampingné. Tingalina suba suud ngambar. Ditu ia mutusang ulah ngambar.

Alih bahasa : dirinya satupun belum ada menggambar. Gede menghela nafas, bagaimana caranya menggambar, rumah tidak punya.

Seperti pernyataan diatas, di tengah cerita ini diceritakan tentang inti dari cerpen tersebut. Inti dari cerpen ini menceritakan tentang kegelisihan seorang anak yang tidak bisa membayangkan mempunyai rumah yang pasti, maka dari itu dia membayangkan mempunyai rumah bagus lengkap dengan harta benda yang ada di dalamnya

c. Akhiran
Pada bagian akhir, disini menceritakan tentang pengupulan tugas menggambar dari pak Guru Gusti Sukadana, seperti penggalan di bawah ini.

Kuipan : Pagrudug murid-muridé ané suba suud ngambar ngojog genahné Pak Guru Gusti Sukadana malinggih. Gedé Wiradana nu negak di tongosné. Bengong. Sing aséna, potlot ané gisina uli tuni, ulung ka bataran kelasé.

Alih bahasa : para siswa terburu-buru untuk mengumpulkan gambaran, sedangkan Gede Wiradana satupun tidak ada mengambar

Menurut kutipan diatas, menurut Sugiarto (2013:205) menyatakan pada tahap akhir ini memberikan pesan akhir dari cerita ini. Pada kutipan diatas kutipan terakhir menjelaskan tentang datangnya Bapak Guru Gusti Sukadana ke dalam kelas tetapi GedeWiradana belum membuat satu pun gambaran

\section{f. Amanat}

Amanat adalah pesan moral yang ingin disampaikan oleh pengarang melalui karyanya. Amanat disampaikan oleh pengarang secara implicit yaitu memberikan pesan moral yang tersirat jadi, kita yang menyimpulkan pesan moralnya. Sedangkan amanat disampaikan secara eksplisit yaitu memberikan pesan moral secara tersurat melalui seruan,saran,peringatan,pesan atau larangan yang berkaitan dengan cerita. Amanat yang disampaikan oleh pengarang dalam cerpen "umah" ini terlihat pada penggalan berikut: 
Kutipan : Kapin makelo sing kacunduk, Sagung Dwipayani tetep ngirim séwala patra tekén méménné. Méménné masi tetep ngirim surat. Di kapah-kapahé, Gedé Wiradana orahina maca séwala patrané Sagung Dwipayani.Biangné Sagung Dwipayani tengkejut nyingakin sapatekan méménné. Ida raris nandan méménné tur ngaukin déwékné ka purian. Sayan tengkejut biangné Sagung

Alih bahasa : ibunya Sagung Dwipayani terkejut melihat ibunya GedeWiradana, beliau lalu menuntun ibunya Gede untuk masuk ke puri. Lagi ibunya Sagung Dwipayani terkjut saat ibunya Gede menuturkan masalahnya, lalu bunyi mobil dari garasi memotong pembicaraanya. "itu Sagung sudah datang". Kata ibunya

Pada kutipan tersebut sudah disebutkan amanat yang ada pada cerpen "umah". Amanat yang disebutkan yaitu, kesetiaan seorang sahabat yang tidak ternilai harganya, iklas membantu teman pada saat dia mengalami kesulitan. Ketika lama tak bertemu teman kita juga diajarkan untuk tidak melupakan teman dengan cara terus mengirimkan surat atau kabar pada teman kita. Kita sebagai calon pendidik juga dituntut untuk mengikuti sikap dari Bapak Guru Gusti Sukadana yang bijaksana dalam memberikan tugas pada siswa.

\section{KESIMPULAN}

Sastra (Sanskerta: shastra)

merupakan kata serapan dari bahasa Sanskerta 'Sastra', yang berarti 'teks yang mengandung instruksi" atau "pedoman", dari kata dasar 'Sas' yang berarti "instruksi" atau "ajaran" dan 'Tra' yang berarti "alat" atau "sarana". Dalam bahasa Indonesia kata ini biasa digunakan untuk merujuk kepada "kesusastraan" atau sebuah jenis tulisan yang memiliki arti atau keindahan tertentu.
Yang agak bias adalah pemakaian istilah sastra dan sastrawi. Segmentasi sastra lebih mengacu sesuai defenisinya sebagai sekedar teks. Sedang sastrawi lebih mengarah pada sastra yang kental nuansa puitis atau abstraknya. Istilah sastrawan adalah salah satu contohnya, diartikan sebagai orang yang menggeluti sastrawi, bukan sastra.

Selain itu dalam arti kesusastraan, sastra bisa dibagi menjadi sastra tertulis atau sastra lisan (sastra oral). Di sini sastra tidak banyak berhubungan dengan tulisan, tetapi dengan bahasa yang dijadikan wahana untuk mengekspresikan pengalaman atau pemikiran tertentu.

astra bukanlah seni bahasa belaka, melainkan suatu kecakapan dalamenggunakan bahasa yang berbentuk dan bernilai sastra

cerpen umah ini menceritakan perjuangan seorang anak yang sama sekali tidak memiliki rumah yang layak, ketika diberitahu untuk membuat gambaran rumah oleh gurunya Gede Wiradana malah bengong tidak tahu bagaimana

\section{DAFTAR PUSTAKA}

Somad A.A. et.al. 2009. Aktif dan Kreatif Berbahasa Indonesia. Bandung: pusat perbukuan departemen pendidikan nasional.

Djuharmie, et.al. 2005. Bahasa Indonesia. Bandung: $\mathrm{CV}$ regina.

Warsanto Sahid I, et.al. 2004. Kaji Latih Bahasa dan Sastra Indonesia. Jakarta: bumi aksara.

Fitri A.A. (2016). pengertian-cerpen-ciri-ciristruktur-unsur-intrinsik-unsurekstrinsik.

[online] Tersedia http://gopengertian.blogspot.com[12 maret 2016] 